\title{
A vena cava inferiorból kiinduló primer leiomyosarcoma esete
}

\author{
Weninger Csaba dr. ${ }^{1, *}$ - Várady Edit dr. ${ }^{1}$ - Omar Giyab dr. ${ }^{1}$ \\ Szabó Imre dr. ${ }^{2}$. Tornóczky Tamás dr. ${ }^{3}$
}

\author{
${ }^{1}$ Pécsi Tudományegyetem, Általános Orvostudományi Kar, Klinikai Központ, Radiológiai Klinika, Pécs \\ ${ }^{2}$ Pécsi Tudományegyetem, Általános Orvostudományi Kar, Klinikai Központ, Belgyógyászati Klinika, Pécs \\ ${ }^{3}$ Pécsi Tudományegyetem, Általános Orvostudományi Kar, Klinikai Központ, Pathologiai Intézet, Pécs
}

\begin{abstract}
A hasi és retroperitonealis (például vese, máj) daganatokkal összefüggő vénás invázió viszonylag gyakori. Az elsődleges vascularis (vénás) daganatok azonban ritkák, szokatlanok. A szerzők egy 67 éves nóbeteg esetét ismertetik, akit rossz általános állapotban, icterusosan utaltak kórházba. Laboratóriumi leletei máj- és veseelégtelenséget mutattak. A hasi ultrahangvizsgálat egy nagy retroperitonealis terimét mutatott, lehetséges uterinalis eredettel. A hasi CT-vizsgálat is retroperitonealis folyamatot ábrázolt, amely magában foglalta a vena (v.) cava inferiort hasüregi vagy kismedencei tumor egyértelmű jele nélkül. A beteg rossz átalános állapotára tekintettel mútétet nem végeztek, a beteg néhány napos ápolás során meghalt. A boncolás a v. cava inferior primer leiomyosarcomáját igazolta. Szakirodalmi adatok alapján a v. cava inferior primer leiomyosarcomája kifejezetten ritka. A v. cava inferior leiomyosarcoma különböző tüneteket képes okozni, attól függően, hogy a véna melyik részét érinti a kórfolyamat. Sebészi beavatkozás a betegség korai stádiumában végezhető el, rossz prognózisú. A v. cava inferiort magában foglaló, bizonytalan retroperitonealis daganatok esetén a radiológusnak gondolnia kell a vascularis eredetü daganat lehetőségére is. Orv Hetil. 2019; 160(19): 756-761.
\end{abstract}

Kulcsszavak: leiomyosarcoma, vena cava inferior, számítógépes rétegvizsgálat (CT)

\section{A case of primary leiomyosarcoma originating from the inferior vena cava}

The venous invasion from intraabdominal and retroperitoeal tumors (e.g., liver and kidney) is relatively frequent. Primary vascular (venous) tumors are uncommon. The authors review the case of a 67 -year-old woman, who was admitted to the hospital in a poor general condition with jaundice. Laboratory findings indicated hepatic and renal insufficiency. Abdominal ultrasound detected a large retroperitoneal mass which was suspected to be of uterine origin. Abdominal CT showed a retroperitoneal mass that invaded the inferior vena cava, but there was no sign of primary intraabdominal or pelvic tumor. Due to the poor general condition of the patient, surgery was not performed. The patient died in some days after admission. Autopsy revealed a primary leiomyosarcoma of the inferior vena cava. Based on the literature data, primary leiomyosarcoma of the inferior vena cava is extremely rare. Leiomyosarcoma of the inferior vena cava can cause various symptoms, depending on the involved segment of the vein. Surgical intervention can be performed in early stages of the disease. In uncertain retroperitoneal tumors involving the inferior vena cava, radiologists should think of the possibility of tumor with vascular origin.

Keywords: leiomyosarcoma, inferior vena cava, computed tomography

Weninger Cs, Várady E, Omar G, Szabó I, Tornóczky T. [A case of primary leiomyosarcoma originating from the inferior vena cava]. Orv Hetil. 2019; 160(19): 756-761.

(Beérkezett: 2018. december 7.; elfogadva: 2019. január 31.) 


\section{Rövidítések}

$\mathrm{CT}=$ (computed tomography) számítógépes tomográfia; FNCLCC $=$ (Fédération Nationale des Centres de Lutte Contre le Cancer) Francia Nemzeti Rákellenes Központok Szövetsége; gamma-GT = gamma-glutamil-transzferáz; GIST $=($ gastrointestinal stromal tumor $)$ gastrointestinalis stromalis tumor; GOT = glutamát-oxálacetát-aminotranszferáz (= ASAT); GPT = glutamát-piruvát-aminotranszferáz (= ALAT); HPF = (high-powered field) mitiózis index, a mitotikus sejtek számát adja meg 10 nagy nagyítású látótérre vonatkoztatva; $\mathrm{LDH}=$ (lactate dehydrogenase) laktát-dehidrogenáz; MRI = (magnetic resonance imaging) mágnesesrezonancia-képalkotás; PET = (positron-emission tomography) pozitronemissziós tomográfia; $\mathrm{SMA}=$ simaizomaktin; $\operatorname{Trc}=$ thrombocyta $; \mathrm{UH}=$ ultra hang

A retroperitonealis - pancreas- vagy veseeredetú - malignus daganatok gyakoriak. A vese- vagy májdaganat beterjedhet a vénákba, a vena (v.) renalis, v. cava másodlagos malignus érintettsége is viszonylag gyakori. Modern radiológiai módszerekkel (UH, CT, MRI) ezt mútét elótti időszakban fel lehet ismerni. Esetünkben az icterus, máj- és vesefunkciós laboreltérések hátterében $\mathrm{UH}^{-}$, CT-vizsgálat retroperitonealis, a v. cavát érintő daganatot mutatott ki. Mútétre a beteg rossz általános állapota miatt nem kerülhetett sor, a sectio a v. cava inferior leiomyosarcomáját igazolta.

\section{Esetismertetés}

Egy 67 éves nőbeteget utalt családi orvosa elesett állapotban icterus miatt a helyi kórház belgyógyászati ambulanciájára sürgősséggel. Fizikális vizsgálat, laboratóriumi és radiológiai vizsgálat és néhány konzílium történt. A fizikális vizsgálat során tapasztalt eltérések: icterusos bőr, közepes fokú lábszárödéma; a jobb oldalon basalisan tompulat volt kopogtatható. A has puha volt, betapintható, a máj l harántujjal nagyobb. Laboratóriumi vizsgálatai közül kiemelendő a magas bilirubinszint $(65,8 \mu \mathrm{M} / \mathrm{l})$, az ASAT (GOT) és ALAT (GPT) 3000 $\mathrm{U} / 1$ felett, a gamma-GT $167 \mathrm{U} / \mathrm{l}$, az LDH csaknem $3700 \mathrm{U} / 1$ volt; karbamid: $26,5 \mathrm{mM} / 1$, kreatinin: 215 $\mu \mathrm{M} / \mathrm{l}$, ammónia: $110 \mu \mathrm{M} / \mathrm{l}$; a C-reaktív protein szintén magas volt, $60 \mathrm{mg} / \mathrm{l}$.

Epelefolyási akadály, cholecystitis, pancreatitis iránydiagnózissal küldték hasi ultrahangvizsgálatra, melynek során a hasban szabad folyadék ábrázolódott a lép és a máj körül és a kismedencében. A máj nagyobb volt, inhomogén. Az uterus kifejezetten inhomogén volt, az endometrium echódús. A retroperitoneum jobb oldalán nagy, $8 \times 9 \mathrm{~cm}$ átmérójǘ, $14-15 \mathrm{~cm}$ hosszú inhomogén, echószegény terime volt látható, amely éles szélű volt. Az UH-kép alapján endometrium-térfoglaló folyamat volt valószínúsíthető retroperitonealis daganattal. Nőgyógyászati konzílium során közepesen nagy méhet találtak, szivárgó uterinalis vérzéssel.
Tüneti kezelés zajlott a megfigyelési időszakban (glükóz, Ringer-laktát, furoszemid, fitomenadion/ K-vitamin). A kezelés hatására a zavartság csökkent. További ellátás, vizsgálatok miatt került a beteg a szerzók intézetébe.

Áthelyezést követően az előző napi fizikális vizsgálattal megegyező́t találtunk. Aluszékony volt, ébreszthető. A beteget gasztroenterológiai osztályra vették fel. Itt folytatódtak a laboratóriumi vizsgálatok, beleértve a toxikológiai és vírusszerológiai vizsgálatokat is. Centrális vénás katéter behelyezése történt. Mellkasi röntgenvizsgálat és hasi, kismedencei CT-vizsgálat történt.

A laboratóriumi paraméterek változatlanul kórosak voltak, a bilirubin, a GOT, a GPT magas értéket mutatott, a transzaminázok az előző vizsgálat óta tovább növekedtek. Ezek számszerú értékei: $70,7 \mathrm{mmol} / \mathrm{l}, 6251$ és 3942. CRP: 49,68, fehérvérsejt: 22,88 G/1. Kreatinin: $196 \mathrm{mmol} / \mathrm{l}$. A vérlemezkeszám alacsony volt, 65 $\mathrm{G} / 1$.

A mellkasi röntgenvizsgálat csekély mennyiségú jobb oldali mellúri folyadékot, a jobb oldalon a szív-rekesz szögletben beszúrődést, kis vérköri pangást igazolt. Metasztázis nem ábrázolódott.

Többfázisú mellkasi és hasi CT-vizsgálat történt (Somatom Definiton berendezéssel; Siemens, München, Németország), natív és posztkontrasztos mérésekkel. Mindkét oldalon dorsalisan kevés, sarló alakú folyadék volt, amely a carina szintjében jobb oldalon $20 \mathrm{~mm}$, bal oldalon $10 \mathrm{~mm}$ vastag volt. Az alsó lebenyekben a folyadék előtt atelectasia ábrázolódott.

A máj szabályos méretú, homogén volt, környezetében kevés, $\mathrm{l} \mathrm{cm}$-nél kevesebb folyadék látszott. A lép normális méretû volt, környezetében $4-8 \mathrm{~mm}$ folyadékkal. A v. cava inferior szív alatti részében a lumenben kontrasztanyag ábrázolódott, a kontrasztanyaggal kitöltött érlumen mérete distalisan fokozatosan csökkent, majd eltünt. A májvénákban érdemi kontrasztanyag-halmozás nem látszott. A v. cava inferior intrahepaticus szakasza tág, 4,5 ×6 cm, inhomogén volt. A mellékvesék és a vesék épek voltak, vesedaganat nem volt felismerhető. A pancreas mögött a v. cava inferior régiójában az axialis síkban mérve 7,5 × 8,5 cm-es, éles szélú terime volt látható, amely ventral felé diszlokálta a pancreast. A v. portae hepatis is ívben diszlokált volt. A v. cava inferior lumenét minimális kontrasztanyag-halmozást mutató terime töltötte ki. A pancreas ép volt, ductustágulat nem mutatkozott. Az aortabifurcatio szintje felett kb. $4 \mathrm{~cm}$ rel a v. cava inferior $18 \mathrm{~mm}$ átmérőjü, szabályos kontrasztanyag-halmozást mutatott. E véna mellett tág kollaterális ábrázolódott. A v. cava inferior régióbeli terime craniocaudalis kiterjedése $\mathrm{kb} .16-17 \mathrm{~cm}$ volt.

Az uterus anteflektált helyzetú, inhomogén szerkezetû volt. Mellette mindkét oldalon folyadék látszott. Vélemény: nagy kiterjedésú retroperitonealis, a v. cavából kiinduló vagy azt magában foglaló térfoglaló folyamat. Ennek eredete lehet a v. cava fala, kisebb valószínüséggel a pancreas vagy retroperitoneum szövete (1-4. ábra). 


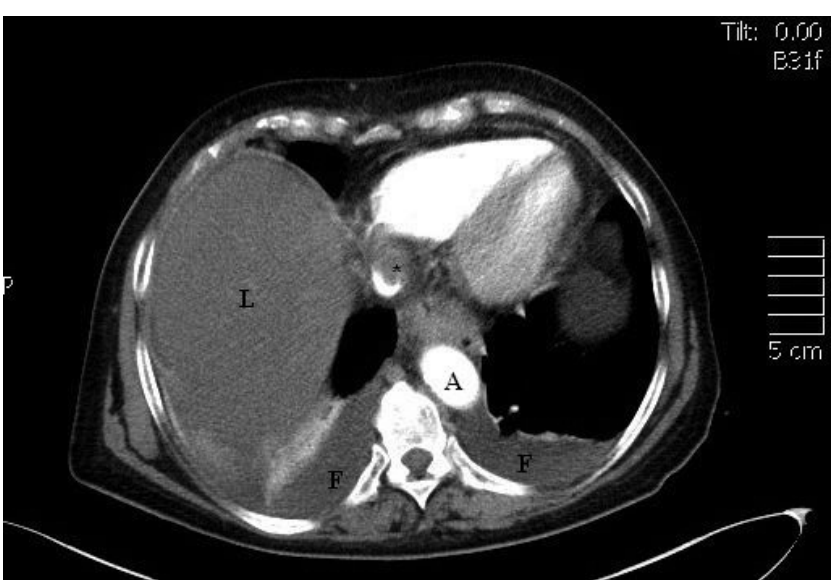

1. ábra

CT-felvétel a mellkas-has átmenetében. A felvételen a máj (L) felső része és az aorta $(\mathrm{A})$ átmetszete látható. Pleuralis folyadék (F) van a dorsalis sinusokban. A vena cava inferior (*) elülsó része nem halmozza a kontrasztanyagot, azonban dorsalisan sarló alakú, kontrasztanyagot jól halmozó részlet látszik

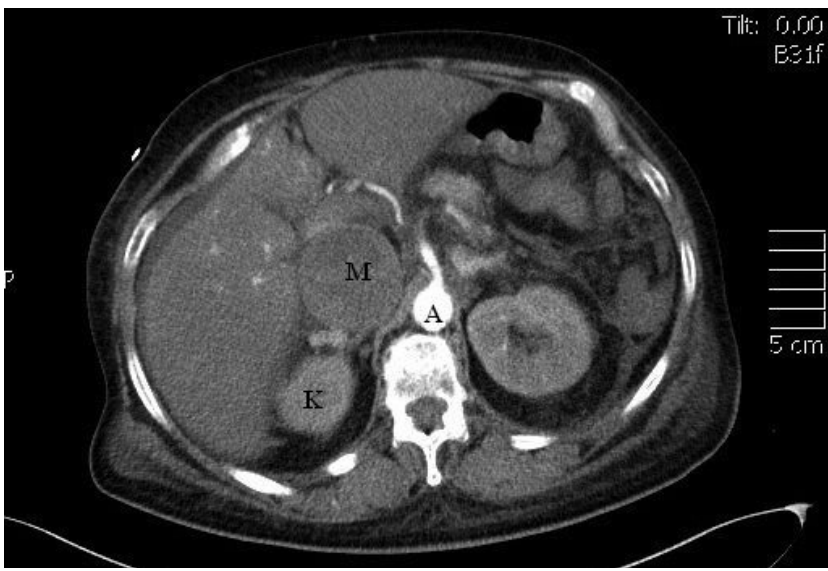

2/a ábra

Hasi CT felvétele a truncus coeliacus eredésének szintjében; artériás fázisú kép. Térfoglaló folyamat $(\mathrm{M})$ látható a jobb vese (K) előtt a retroperitonealis térben, a vena cava inferior várható helyén. Az artériás fázisú leképezésre tekintettel, a hasi aorta $(\mathrm{A})$ magas kontrasztanyag-tartalmú

A fenti leletet adó vizsgálatot követően sebészeti konzílium történt; a CT-vizsgálat ismeretében inoperábilisnek tartották a hasi folyamatot. Az alvadási paraméterekre tekintettel, perkután biopszia nem jött szóba.

Időközben sikerült telefonon elérni a családot, hozzátartozókat, akik elmondták: 20 éve ismert a beteg hipertenziója. Egyéb testi betegsége nem volt. Elmondásuk szerint pszichiátriai ok miatt a beteget leszázalékolták, pontos okot nem ismertek. Korábban többször említett hasi, háti fájdalmat.

A toxikológiai vizsgálat kis mennyiségű tramadolt, metamizolt, metabolitokat igazolt a vizeletből, illetve alacsony szérumacetaminofent (mindet a terápiás menynyiségen belül).

A továbbiakban a beteget tünetileg kezelték (best supportive care). Kórházi felvétele 3 . napján, hajnalban a beteg meghalt. A halál okának, a retroperitonealis térfog-

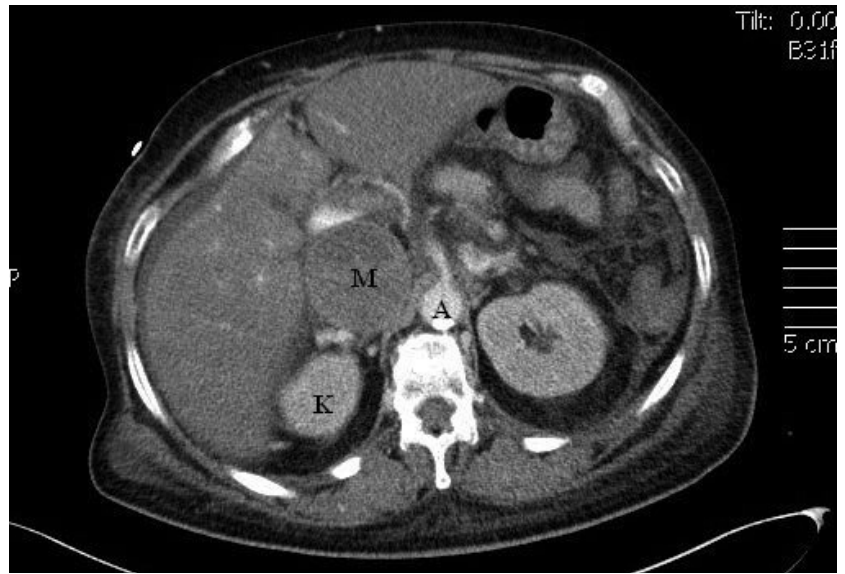

2/b ábra $\quad$ Ez a kép ugyanabban a magasságban készült, mint az előző, 2/a ábra, csak más időzítésben, vénás fázisban

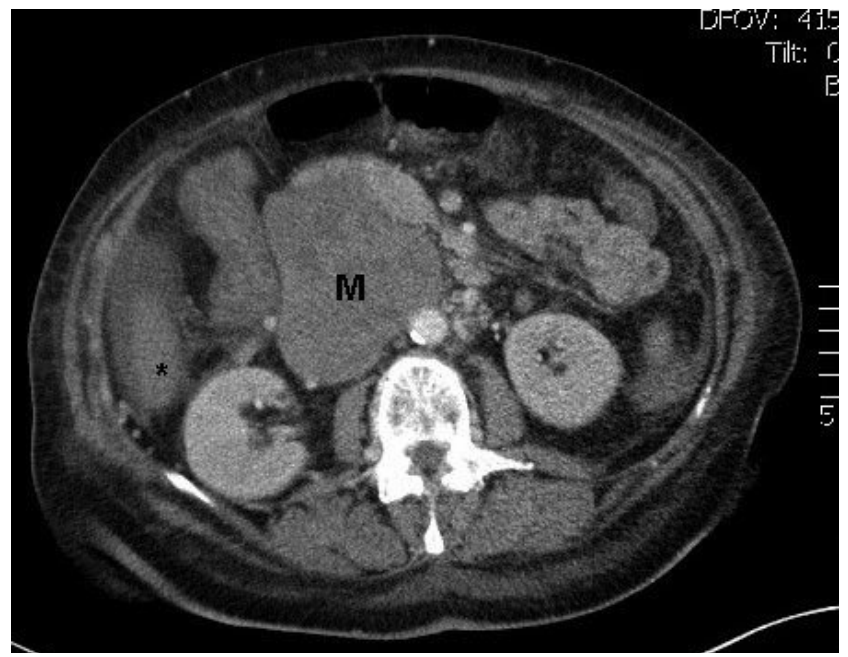

3. ábra

Vénás fázisú axiális síkú hasi CT-felvétel a máj alsó pólusának (*) magasságában. A vesék középső-alsó harmada a kép alsó részén ábrázolódik. Nagy kiterjedésű, kissé heterogén, nem kifejezett kontrasztanyag-halmozású szabálytalan átmetszetű terime $(\mathrm{M})$ a retroperitoneum hátsó részében

laló folyamat természetének megállapítása érdekében sectióra került sor.

Patológiai vizsgálat: a v. cava inferiorban a v. hepaticák betorkollásától kb. 10-12 cm-es szakaszon egy szürkésfehér színű, közepesen tömött tapintatú tumor van, amely az ér lumenét teljes mértékben kitölti. A v. cava inferiorból annak ágrendszerén keresztül a daganat oldalra is terjed a mesenteriumgyök irányába. A máj kb. 1600 gramm tömegű, zöldes alaptónusú, a metszlapokon élénk szerecsendiórajzolatot, illetve centralis haemorrhagiás necrosis rajzát mutatja. A pancreas mirigyes szerkezetü, megtartott morfológiájú, a tumortól 2-3 harántujjnyira helyezkedik el a fej. A v. cava inferior lágyrész-daganatának szövettani vizsgálata leiomyosarcomát igazolt. Az orsósejtes fenotípusú daganat élénk, diffúz simaizomaktin-, dezmin- és h-kaldezmon-reakciót adott a sejtek citoplazmájában. A mitotikus aktivitás alacsony 


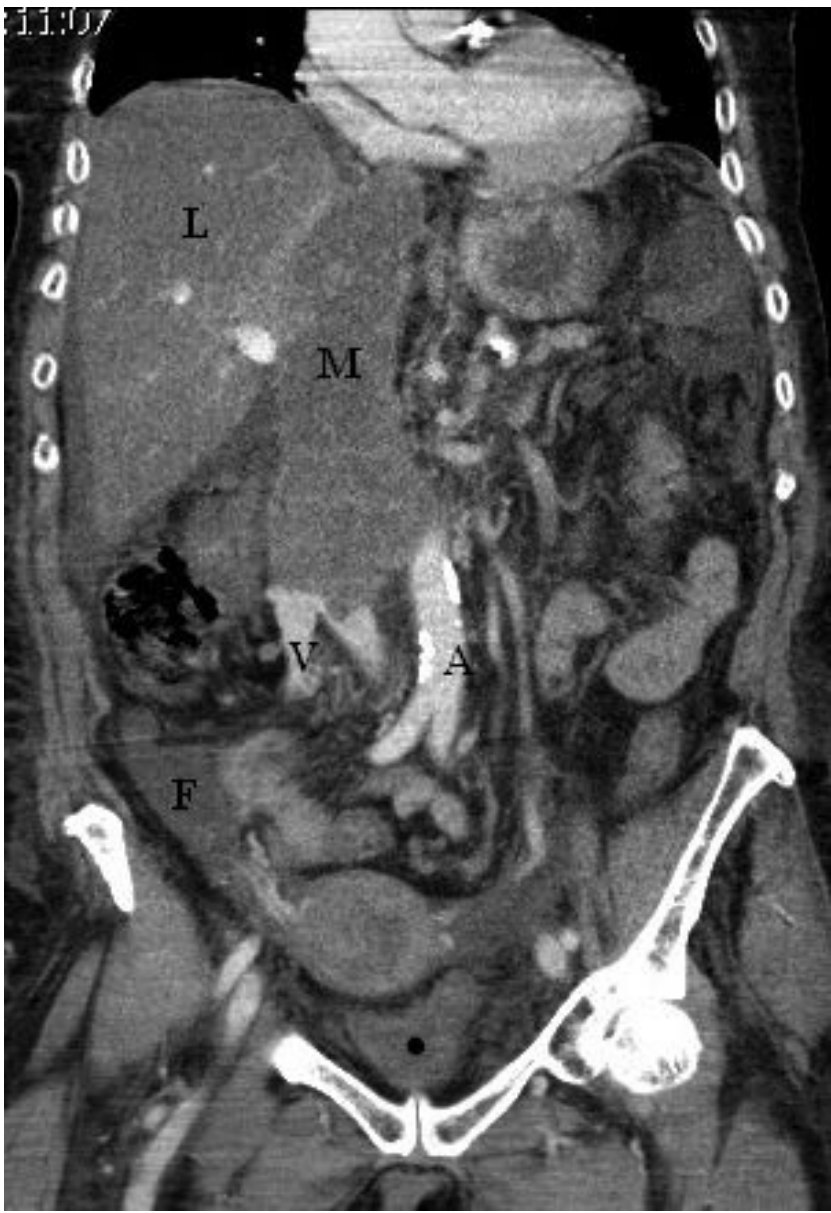

4. ábra

Coronalis hasi CT-felvétel; vénás fázisú. Térfoglaló folyamat (M) látható lényegében a rekesztól a vena cava inferior alsó szakasza, a vena iliaca communisok (V) összeömlése között. A has aorta (A) ábrázolódott alsó szakasza kontrasztanyaggal kitöltött, mint ahogy a vena iliaca communisok is. Mivel a vena cava inferior kiszélesedett, a vena iliacák összeömlése magasabban van, mint az aortabifurkáció. A kismedence jobb oldalán kevés folyadék $(\mathrm{F})$ van $(\mathrm{L}=$ máj$)$

volt (1/10 HPF), nekrózis gyakorlatilag nem volt, a tumor a FNCLCC szerint G I-es volt (a lágyrész-sarcomák osztályozására használatos rendszer alapján, melyet a Fédération Nationale des Centres de Lutte Contre le Cancer dolgozott ki) (5. és 6. ábra).

A halál hátterében vese- és májelégtelenség, szívelégtelenség állt.

Diagnózis: leiomyosarcoma venae cavae inferioris; icterus hepatis; haemorrhagica centralis hepatis; infiltratio adiposa myocardii; degeneratio adiposa diffusa myocardii.

\section{Megbeszélés}

A vascularis eredetú primer malignus daganatok ritkák. Az erek falában lévő simaizomsejtekből leiomyosarcoma alakulhat ki. A leggyakrabban a v. cava inferiorból indul ki. Napjainkban néhány száz esetet publikáltak. Ez a kórkép rendszerint a 60 év feletti nők betegsége [1-5]. A v.

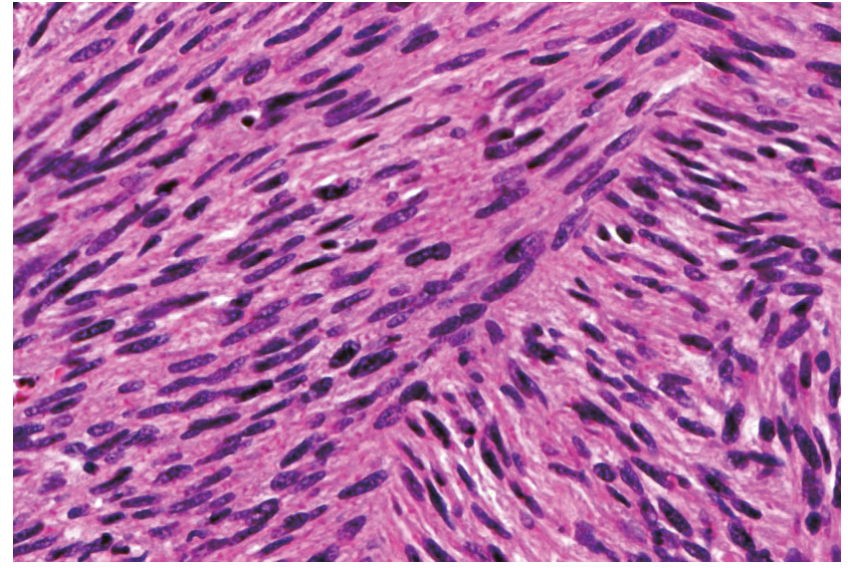

5. ábra

Leiomyosarcoma mikroszkópos képe (hematoxilin-eozin festés, nagy nagyítás). A faszcikulált elrendezést mutató daganatsejtek jellegzetes lekerekített végü, szivar alakú magokkal, eosinophil plazmával rendelkeznek, amelynek filamentosus struktúrája is megfigyelhető

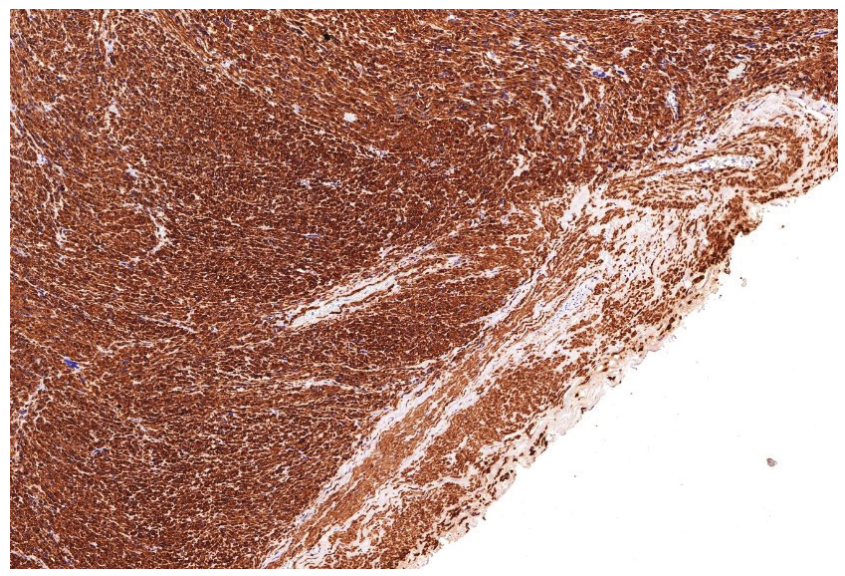

6. ábra

Leiomyosarcoma (simaizomaktin [SMA] immunhisztokémiai reakció, kis nagyítás). Diffúz, erős cytoplasmalis immunreakció a daganatsejtekben. A metszet jobb szélén a vena cava inferior falrészletének rendezett simaizom-állománya ábrázolódik

cava inferior leiomyosarcoma esetét több szerző szerint Perlírta le először 1871-ben [1-3, 6].

A tünetek aspecifikusak, és attól függenek, hogy a daganat a v. cava inferior melyik szakaszát érinti. Ez az ér három szakaszra osztható: a) felső szegmentum: rekeszkupola és a v. hepaticák közötti rész; b) középső szegmentum: a v. hepaticák és a v. renalisok közötti szakasz; c) alsó szegmentum: a v. renalisok szintje alatti szakasz. A daganat növekedhet intra-, extraluminalisan, mindkét irányban; az intramuralis növekedés extrém ritka $[1,3$, 5-11]. E betegség patogenezisének és természetének vizsgálatára nemzetközi regisztert alapítottak, melyet Mingoli és mtsai vezettek be 1992-ben (The International Registry of Inferior Vena Cava Leiomyosarcoma) [5]. 1996-ban 218 beteget tartottak nyilván [5], 2010-ben körülbelül 400-at [12].

Amennyiben a véna felső szakasza érintett, akkor Budd-Chiari-szindrómának megfelelő klinikai kép alakul ki, májfunkciós zavar, májelégtelenség. Hasi fájdalom, 
hányinger, ascites, icterus fejlődik ki. A középső szakasz érintettsége esetén felhasi fájdalom alakul ki, amely epebetegség benyomását keltheti, illetve vesebetegség klinikuma jelenhet meg. Nagy hasi daganat okozhat háti vagy radicularis fájdalmat. Az alsó szakasz izolált érintettsége alsó végtagi duzzanatot okoz $[1,3,5-8,13]$. A bemutatott beteg kora és neme típusos. Kórházba kerülésekor máj- és vesefunkciós eltéréseket lehetett kimutatni, a májelégtelenség tünetei. A kiterjedt, hosszú szakaszú vénaelzáródás ellenére alsó végtagi duzzanat nem volt megfigyelhető, feltehetően a viszonylag lassú progreszszió miatt volt idő kollaterálisok kialakulására.

A vénafalból kiinduló tumor patológiailag lassan növő, alacsony malignitású, azaz low grade malignus daganat. Rendszerint csak későn okoz áttéteket. Amennyiben metasztázis alakul ki, annak típusos helyei: tüdő, máj, nyirokcsomó, ritkán mellékvese, csont, vese, pancreas, pleura $[2,3,6,8,10,14,15]$. A leiomyosarcoma típusos szövettani jellemzői: örvénylő kötegekbe rendeződő, orsó alakú daganatsejtek, elongált vagy tompa végú nucleusszal [10].

Ez a daganat simaizom-eredetü; a fenotípusos jegyek mellett a simaizommarkerek alapján diagnosztizálható, melyek a simaizomaktin (SMA), a dezmin és a h-kaldezmon. Ezek a markerek az esetek több mint 70\%-ában pozitívak. Az előbbi kettő nem teljesen specifikus a simaizomra, de a h-kaldezmonnal kombinálva, illetve a szövettani jellegzetességekkel együtt a leiomyosarcoma biztonsággal diagnosztizálható $[16,17]$.

A diagnózist ma UH, color-Doppler-UH és CT biztosítja $[1,3,6,16]$, melyeket kiegészíthet az MRI, MRangiográfia $[2,9,10,13,16,18,19]$. A korábban használt klasszikus radiológiai módszereknek (kiválasztásos urográfia, báriumos gyomor-bél rendszeri vizsgálatok, katéteres angiográfia $[3,4,10])$ napjainkban már nincs szerepük. Ezek mellett egyes szerzők a vénás kollaterálisok kimutatására kavográfiát végeztek [8]. A tumor növekedésével a véna átmérője nő. A véna lumenében lévő daganatszövet heterogén, és rendszerint intenzív kontrasztanyag-halmozást mutat, ami megkülönbözteti a thrombustól, esetenként azonban a daganat nem vagy alig veszi fel a kontrasztanyagot $[6,18]$. Saját betegünk esetén a tumor kontrasztanyagot alig halmozott, ez eltér az irodalomban leírt megszokott radiológiai megjelenéstől. A PET/CT segíthet az intraluminalis tumor és a thrombus elkülönítésében [20].

A retroperitonealis térfoglaló folyamatok esetén az elkülönítő diagnosztikában az alábbi kórképek jönnek szóba a közleményben szereplő mellett: nyirokcsomó-eredetû daganatok (malignus lymphoma, nyirokcsomó-metasztázis); lágyrész-sarcomák (liposarcoma); neurogén daganatok (neurofibroma, schwannoma, ganglioneuroma, paraganglioma); csírasejtes tumorok (teratoma); retroperitonealis szervekből származó daganatok (vese, mellékvese). Szóba jönnek még nem daganatos kórképek is, mint például haematoma, retroperitonealis fibrosis, Castleman-betegség [16]. A felsoroltakon kívül a retroperitonealis térfogaló folyamat hátterében még gastrointestinalis stromalis tumor (GIST) is állhat.

A prognózis kedvezőtlen. Csak a resectio kecsegtethet sikerrel, amelyet nem lehet mindig elvégezni a környező szövetek érintettsége miatt. Az ötéves túlélés elérheti radikális mütét esetén a 38-56\%-ot a tumor kiindulási helyétől függően. Az egyéb kezelések - kemoterápia, radioterápia, radiokemoterápia - hatása kétséges, a kevés betegre tekintettel nincsenek nemzetközileg elfogadott protokollok [1, 3, 5-8, 14]. Egyes szerzők szerint a radikális mútét adjuváns multimodális terápiával kombinálva $62 \%$-os éves túlélést eredményezhet [9]. A resectio melletti lehetőségek a ligatio, a primer rekonstrukció vagy a graftbeültetés $[5,9,11]$. Mingoli adatai szerint a legrosszabb túlélési esélyek a v. cava inferior alsó szegmentumából kiinduló daganatok esetén állnak fenn [5]. Egyes szerzők vitatják a vénarekonstrukció szerepét [2], más szerzők ajánlják, fontosnak tartják $[8,9]$. A szakirodalomban ismert egy hazai eset, amikor mútétet követően 8 évvel recidíva alakult ki; ismételt mútéttel a recidíva is eltávolítható volt [7]. A betegek száma alacsony, ezért prospektív randomizált tanulmányok nem állnak rendelkezésre a kezelésre vonatkozóan [2]. Hines és mtsai 14 beteg sebészi kezelésével szerzett tapasztalatait ismertetik [19].

\section{Következtetés}

Az esetet ritka előfordulása miatt tartottuk érdemesnek közölni. A vénafalból kiinduló primer leiomyosarcoma lehangoló prognózissal rendelkezik. Esetünkben megfelelő módszerrel, hasi CT-vel a kórképet diagnosztizálni lehetett. Tekintettel arra, hogy az ismertetett beteg igen későn került orvoshoz panaszaival, mútét már nem jött szóba, a végleges, szövettani diagnózist a sectio és nem a mútét előtti perkután biopszia vagy a mütéti anyag szövettani feldolgozása adta meg. Bizonytalan retroperitonealis daganat esetén gondolni kell a vascularis eredetü tumor lehetőségére.

Anyagi támogatás: A szerzők anyagi támogatásban nem részesültek.

Szerzői munkamegosztás: W. Cs.: Irodalomkutatás, az ismertetett radiológiai vizsgálat leletezése, a kézirat megszövegezése és ellenőrzése, az ábrák készítése. V. E., O. G.: A kézirat ellenőrzése. Sz. I.: Klinikai adatok szolgáltatása, a kézirat ellenőrzése. T. T.: A patológiai és szövettani vizsgálat elvégzése, a patológiai adatok szolgáltatása. A cikk végleges változatát valamennyi szerző elolvasta és jóváhagyta.

Érdekeltségek: A szerzőknek nincsenek érdekeltségeik. 


\section{Irodalom}

[1] Abisi S, Morris-Stiff GJ, Scott-Coombes D, et al. Leiomyosar coma of the inferior vena cava: clinical experience with four cases. W J Surg Oncol. 2006; 4: 1.

[2] Daylami R, Amiri A, Goldsmith B, et al. Inferior vena cava leiomyosarcoma: is reconstruction necessary after resection? J Am Coll Surg. 2010; 210: 185-190.

[3] Young R, Friedman AC, Hartman DS. Computed tomography of leiomyosarcoma of the inferior vena cava. Radiology 1982; 145: 99-103.

[4] Granmayeh M, Jonsson K, McFarland W, et al. Angiography of abdominal leiomyosarcoma. Am J Roentgenol. 1978; 130: 725730

[5] Mingoli A, Cavallaro A, Sapienza P, et al. International Registry of Inferior Vena Cava Leiomyosarcoma: analysis of a world series on 218 patients. Anticancer Res. 1996; 16: 3201-3205.

[6] Ceyhan M, Danaci M, Elmali M, et al. Leiomyosarcoma of the inferior vena cava. Diagn Interv Radiol. 2007; 13: 140-143.

[7] Biró ZJ, Kalmár NK, Fehér E, et al. Surgical treatment of primary leiomyosarcoma of the inferior vena cava. [Primer vena cava inferior leiomyosarcoma (VCI-LMS) sebészi kezelése.] Magy Seb. 2009; 62: 83-86. [Hungarian]

[8] Hardwigsen J, Balandraud P, Ananian P, et al. Leiomyosarcoma of the retrohepatic portion of the inferior vena cava: clinical presentation and surgical managemant in five patients. J Am Coll Surg. 2005; 200: 57-63.

[9] Alexander A, Rehders A, Raffel A, et al. Leiomyosarcoma of the inferior vena cava: radical surgery and vascular reconstruction. World J Surg Oncol. 2009; 7: 56

[10] Hartman DS, Hayes WS, Choyke PL, et al. From the archives of the AFIP. Leiomyosarcoma of the retroperitoneum and inferior vena cava: radiologic-pathologic correlation. RadioGraphics 1992; 12: 1203-1220.

[11] Moazeni-Bistgani M, Basravi M. Leiomyosarcoma of the inferior vena cava. Asian Cardiovasc Thorac Ann. 2016; 24: 72-74.

[12] Mingoli A, Sapienza P, Brachini G, et al. Surgical treatment of inferior vena cava leiomyosarcoma. J Am Coll Surg. 2010; 211 $145-146$.
[13] Kumar S, Kumar A, Guleria S. Primary leiomyosarcoma of the juxtarenal inferior vena cava: a case report. Indian J Surg. 2013; 75(Suppl 1): 313-315.

[14] Chan G, Kroczak T, Drachenberg D. Leiomyosarcoma of the inferior vena cava with renal metastasis: an unusual case and diagnostic challange. Can Urol Assoc J. 2014; 8: 358-360.

[15] Cooley CL, Jagannathan JP, Kurra V, et al. Imaging features and metastatic patterns of non-IVC retroperitoneal leiomyosarcomas: are they different from IVC leiomyosarcomas? J Comput Assist Tomogr. 2014; 38: 687-692.

[16] Marko J, Wolfman DJ. Retroperitoneal leiomyosarcoma from the radiologic pathology archives. RadioGraphics 2018; 38: 14031420

[17] Tornóczky T. Myogen tumors. In: Szendrői M, Sápi Z, Pápai Zs. (eds.) Diagnostics and therapy of the malignant soft tissue tumors. [Myogen daganatok. In: Szendrői M, Sápi Z, Pápai Zs. (szerk.) Malignus lágyrészdaganatok diagnosztikája és kezelése.] Medicina Könyvkiadó, Budapest, 2017; pp. 245-258. [Hungarian]

[18] Narata M, Okuhata Y, Abe K, et al. Primary leiomyosarcoma of the inferior vena cava: case report. Abdom Imaging 2010; 35 : $481-484$.

[19] Hines OJ, Nelson S, Quinones-Baldrich WJ, et al. Leiomyosarcoma of the inferior vena cava. Prognosis and comparison with leiomyosarcoma of other anatomic sites. Cancer 1999; 85: 1077-1083.

[20] Singh N, Shivdasani D, Karangutkar S. Rare case of primary inferior cava leiomyosarcoma on F-18 fluorodeoxyglucose positron emission tomography-computed tomography scan: differentiation from nontumor thrombus in a background of procoagulant state. Indian J Nucl Med. 2014; 29: 246-248.

(Weninger Csaba dr., e-mail: csaba.weninger@regionvarmland.se, weningercs@gmail.com)

\section{ELADÓ PRAXIS}

Kelet-Pesten, kertvárosi övezetben, 1170 kártyával rendelkező gyermekorvosi praxis eladó. A praxis átlagos havi bevétele 1,8 M Ft. Betegrendelés naponta 2 óra, tanácsadás heti $2 \times 2$ óra.

A körzethez 2 óvoda tartozik. Ügyeleti és iskolai kötelezettség nincs.

A helyettesítés kölcsönösségi alapon müködik.

Központi fekvésű, korszerűen felszerelt rendelő. Hozzáértő asszisztens.

A belépés időpontja megegyezés szerint.

email: alexovicse@gmail.com, Tel: 30/361-2591, esti órákban. 